\title{
Long- and short-term effects of omitting two weekend milkings on the lactational performance and mammary tight junction permeability of dairy ewes
}

\author{
V. Castillo, ${ }^{*}$ X. Such, ${ }^{*}$ G. Caja,${ }^{* 1}$ R. Casals, ${ }^{*}$ A. A. K. Salama, ${ }^{*} \dagger$ and E. Albanell \\ *Grup de Recerca en Remugants, Departament de Ciència Animal i dels Aliments, Universitat Autònoma de Barcelona, 08193 Bellaterra, Spain \\ †Sheep and Goat Research Department, Animal Production Research Institute, 12311 Dokki, Giza, Egypt
}

\begin{abstract}
The long- and the short-term effects of omitting 2 milkings weekly in early (wk 8 to 14) and mid lactation (wk 15 to 22) were investigated in an experiment conducted with a total of 58 dairy ewes (40 Manchega and 18 Lacaune). Ewes submitted to 2 milking omissions were milked twice daily from Monday to Friday (0800 and $1800 \mathrm{~h}$ ), and once daily on Saturday and Sunday (1600 and $1400 \mathrm{~h}$, respectively). Individual data were collected for milk yield (weekly), milk composition (biweekly), and somatic cell count (SCC; monthly). Omitting 2 milkings per week in early lactation tended to decrease milk yield in Manchega ewes $(-15 \%)$, whereas no effects were observed in Lacaune ewes. Averaged milk composition was not modified by milking omissions in either breed. Milking omissions in late lactation did not affect milk yield and milk composition in either breed. The SCC were unaffected by milking omissions in both breeds and in both stages of lactation. A sample of 22 Manchega and 11 Lacaune ewes were used to evaluate the short-term (daily) effects of the 2 milking omissions per week on milk yield and composition, udder health, and tight junction permeability, both in early lactation (wk 12) and in mid lactation (wk 20). Milking omission decreased milk yield, milk fat, and milk lactose contents on the first omission day in both breeds, with losses being more noticeable in early lactation than in mid lactation. Milk protein content and SCC did not vary by effect of the weekend milking omissions. After restoring the twice-daily milking routine on Monday, milk yield showed a compensatory increase that was greater in the large-cisterned than in the small-cisterned ewes, which allowed milk yield to return to Friday values in both breeds. Milk fat content increased during Sunday and Monday, reestablishing Friday values thereafter in both breeds. Weekend milking omissions in early lactation caused tight junction leakiness in both
\end{abstract}

Received November 30, 2008.

Accepted March 19, 2009.

${ }^{1}$ Corresponding author: gerardo.caja@uab.es breeds, but mammary epithelia adapted to extended milking intervals when applied successively, recovering their tight state after milking. In mid lactation, the mammary tight junction showed leakiness only in Manchega ewes. In conclusion, 2 milkings per week could be omitted with no negative effects on milk yield, milk composition, and milk SCC values in large-cisterned dairy ewes, as observed in Lacaune and large-cisterned Manchega ewes. Losses in milk yield could be reduced if milking omissions were done from mid lactation in small-cisterned ewes.

Key words: dairy sheep, mammary tight junction, milking omission, milking frequency

\section{INTRODUCTION}

Reduction of daily milking frequency in dairy sheep may be a suitable strategy to decrease milk production costs and to improve the quality of life of the farmer. Recent studies have shown the role of udder cisterns for maintaining high milk secretion rates in dairy sheep (Rovai et al., 2008) and have shown differences in the ability of dairy ewes to tolerate extended milking intervals according to the size of their cisternal udder compartment (Castillo et al., 2008a,b). Large-cisterned ewes [i.e., large cisternal area, great cisternal milk percentage, and delayed tight junction (TJ) opening during milk stasis] adapt better to longer milking intervals than small-cisterned ewes.

Decreasing the milking frequency from twice- to once-daily milking reduces milk yield from 10 to $35 \%$ in dairy ewes (Labussière et al., 1974b; Papachristoforou et al., 1982; Nudda et al., 2002), depending on the individual, breed, stage of lactation, and treatment duration. Occasional milking omission impairs milk yield to a lesser extent without compromising udder health and could be used to reduce labor on family farms during critical days of the week (usually during the weekend). Reported milk yield losses after omitting 1 milking per week vary according to sheep breed and study, ranging from nonsignificant values in Manchega (Huidobro, 1988), Poll Dorset (Knight and Gosling, 
Table 1. Milk yield and udder compartment traits of the experimental dairy ewes according to breed and cisternal size ${ }^{1}$ before beginning the experiment (wk 6 of lactation)

\begin{tabular}{|c|c|c|c|c|}
\hline \multirow[b]{2}{*}{ Item } & \multicolumn{2}{|c|}{ Manchega } & \multicolumn{2}{|c|}{ Lacaune } \\
\hline & Small & Large & Small & Large \\
\hline Ewes, $\mathrm{n}$ & 20 & 20 & 9 & 9 \\
\hline Cisternal area, $\mathrm{cm}^{2}$ & $8.0 \pm 0.4^{\mathrm{b}}$ & $12.9 \pm 0.6^{\mathrm{a}}$ & $12.1 \pm 0.5^{\mathrm{b}}$ & $18.0 \pm 0.3^{\mathrm{a}}$ \\
\hline Cisternal milk, mL & $155 \pm 14^{\mathrm{b}}$ & $239 \pm 15^{\mathrm{a}}$ & $305 \pm 27^{\mathrm{b}}$ & $429 \pm 45^{\mathrm{a}}$ \\
\hline Total milk, mL & $269 \pm 16^{\mathrm{b}}$ & $373 \pm 20^{\mathrm{a}}$ & $431 \pm 24^{\mathrm{b}}$ & $579 \pm 20^{\mathrm{a}}$ \\
\hline Cisternal milk, \% & $57.4 \pm 2.5^{\mathrm{b}}$ & $64.1 \pm 2.3^{\mathrm{a}}$ & $70.3 \pm 3.6$ & $73.8 \pm 3.0$ \\
\hline
\end{tabular}

${ }^{\mathrm{a}, \mathrm{b}}$ Means within a breed without a common superscript are different $(P<0.05)$.

${ }^{1}$ Values are the mean of udder halves after $8 \mathrm{~h}$ of udder filling.

1995), and Assaf (Hervás et al., 2006) to $13 \%$ in Sarda (Casu and Labussière, 1972), 17\% in Manchega (Gallego et al., 1984), and $26 \%$ in Préalpes du Sud (Labussière et al., 1974a). Sheep milk losses are greater than those reported after omitting 1 milking per week in dairy cows and dairy goats, which ranged from 3 to $8 \%$ (Labussière and Coindet, 1968; Le Mens, 1978; Ayadi et al., 2003). Omission of 1 milking per week increases milk fat (Labussière et al., 1974a; Huidobro, 1988) and milk protein contents throughout the lactation in sheep (Labussière et al., 1974a; Knight and Gosling, 1995). However, no changes in milk components have been reported in large-cisterned ewes (e.g., Sarda) from omitting 1 milking per week (Casu and Labussière, 1972). Omitting 2 milkings per week in sheep resulted in milk losses similar to those reported for 1 milking omission per week, ranging between 10 and 26\% (Casu and Labussière, 1972; Hervás et al., 2006).

Moreover, modification of the milking interval affects milk composition in the short term in dairy ewes (McKusick et al., 2002, Castillo et al., 2008a). Thus, omitting 1 or 2 milkings per week markedly increases fat and protein contents in the milk collected on the days after the milking omission in ewes (Casu and Labussière, 1972; Labussière et al., 1974a; Hervás et al., 2006), which dramatically modifies bulk milk composition. Similar results were reported previously in cows (Labussière and Coindet, 1968; Ayadi et al., 2003). Milk composition returns to normal values 2 or $3 \mathrm{~d}$ after the milking omission (Casu and Labussière, 1972; Labussière et al., 1974a; Ayadi et al., 2003). No studies have been carried out in dairy ewes to compare the effects of sheep breed, udder cistern size, and stage of lactation on the lactational response to extended milking intervals under the same management conditions.

The aim of this experiment was to evaluate the longand short-term effects of omitting 2 milkings per week during early and mid lactation, in 2 breeds of dairy sheep characterized by differences in milk yield and udder cistern size. Treatment effects were evaluated on milk yield, milk composition, and TJ permeability.

\section{MATERIALS AND METHODS}

The experimental procedures and animal care conditions were approved by the Ethical Committee of Animal and Human Experimentation of the Universitat Autònoma de Barcelona (reference CEEAH 02/410).

\section{Animals and Management Conditions}

Forty Manchega and 18 Lacaune multiparous dairy ewes, located on the experimental farm of the S1GCE (Servei de Granges i Camps Experimentals) of the Universitat Autònoma de Barcelona, were assigned to the experimental treatments during wk 8 to 22 of lactation. After weaning of the lambs (wk 5), the ewes were machine milked twice daily and milk performance was recorded weekly. At wk 6 of lactation and $8 \mathrm{~h}$ after the a.m. milking, ewes were evaluated for cisternal:alveolar milk partitioning and for half-udder cisternal area as measured by ultrasonography (Castillo et al., 2008b; Rovai et al., 2008). Ewes were classed according to their cisternal area values as large cisterned (Manchega $>10 \mathrm{~cm}^{2}$, and Lacaune $>15 \mathrm{~cm}^{2}$, by half udder) and small cisterned (Manchega $\leq 10 \mathrm{~cm}^{2}$, and Lacaune $\leq 15$ $\mathrm{cm}^{2}$, by half udder). Udder compartment traits by breed and cistern size group are reported in Table 1 . Absence of subclinical IMI $(<5 \mathrm{cfu} / \mathrm{mL})$ was checked by milk sample bacteriology according to the procedure of Salama et al. (2003) to avoid unhealthy udders.

Ewes of each breed were divided into 3 similar experimental groups on the basis of cisternal area by half udder (Manchega, $10.4 \pm 0.5 \mathrm{~cm}^{2}$; Lacaune, $15.0 \pm 0.4$ $\mathrm{cm}^{2}$ ), percentage of cisternal milk (Manchega, $60.0 \pm$ $2.5 \%$; Lacaune, $71.5 \pm 3.5 \%$ ), milk yield (Manchega, $1.33 \pm 0.05 \mathrm{~L} / \mathrm{d}$; Lacaune, $2.30 \pm 0.14 \mathrm{~L} / \mathrm{d}$ ), and milk SCC $\left(\log _{10}\right.$ SCC; Manchega, $5.1 \pm 0.1$; Lacaune, $5.3 \pm$ 0.1 ) in the weeks before the beginning of the experiment (wk 5 to 7 ).

Two milking schedule treatments were applied: control $(\mathbf{C})$, in which ewes (Manchega, $\mathrm{n}=29$; Lacaune, $\mathrm{n}=12)$ were milked twice daily (14 milkings/wk), and 
Table 2. Experimental groups of dairy ewes according to treatment ${ }^{1}$ and breed

\begin{tabular}{|c|c|c|c|c|}
\hline \multirow[b]{2}{*}{ Group } & \multirow[b]{2}{*}{ Breed } & \multirow[b]{2}{*}{ Ewes, $\mathrm{n}$} & \multicolumn{2}{|c|}{ Treatment } \\
\hline & & & Early lactation (wk 8 to 14 ) & Mid lactation (wk 15 to 22 ) \\
\hline \multirow[t]{2}{*}{1} & Manchega & 12 & $\mathrm{C}$ & WO \\
\hline & Lacaune & 6 & & \\
\hline \multirow[t]{2}{*}{2} & Manchega & 11 & WO & $\mathrm{C}$ \\
\hline & Lacaune & 6 & & \\
\hline \multirow[t]{2}{*}{3} & Manchega & 17 & $\mathrm{C}$ & $\mathrm{C}$ \\
\hline & Lacaune & 6 & & \\
\hline
\end{tabular}

${ }^{1}$ Milking treatments were the control (C), in which ewes were milked twice daily (14 milkings/wk), and weekend omitted (WO), in which ewes were milked once daily during the weekend (12 milkings/wk).

weekend omitted (WO), in which ewes (Manchega, n $=11 ;$ Lacaune, $\mathrm{n}=6$ ) were milked once daily during the weekend (12 milkings/wk). Milking treatments were initiated at wk 8 (early lactation) and switched at wk 15 (mid lactation) according to a crossover design with a permanent control group (C-C; Table 2). Ewes from group $\mathrm{WO}$ passing to $\mathrm{C}$ at mid lactation were not included in the $\mathrm{C}-\mathrm{C}$ to avoid carryover effects of the milking omission treatments. Ewes submitted to the WO treatment were milked twice daily from Monday to Friday (0800 and $1800 \mathrm{~h}$ ) and once daily on the weekends (Saturday, 1600 h; Sunday, 1400 h). Monday a.m. milking was done at the regular time $(0800 \mathrm{~h})$, resulting in extended milking intervals from Friday to Saturday (22 h), Saturday to Sunday (22 h), and Sunday to Monday (18 h), compared with regular milkings (Monday to Friday, 10 and $14 \mathrm{~h}$ ).

Milking was conducted in a double-12-stall parallel milking parlor (Westfalia-Surge Ibérica, Granollers, Spain) equipped with recording jars $(2 \mathrm{~L} \pm 5 \%)$ and a low milk pipeline. Milking was performed at a vacuum of $42 \mathrm{kPa}, 120$ pulses/min, and a $50 \%$ pulsation ratio. The milking routine included cluster attachment without udder preparation or teat cleaning, machine milking, machine stripping before cluster removal, and teat dipping in an iodine solution (P3-ioshield, Ecolab Hispano-Portuguesa, Barcelona, Spain).

Ewe groups were located in pens and managed similarly throughout the experiment. Ration was based on a dehydrated mixture of alfalfa hay and fescue hay fed ad libitum (1.02 Mcal of $\mathrm{NE}_{\mathrm{L}} / \mathrm{kg}$ and $14.5 \% \mathrm{CP}, \mathrm{DM}$ basis) and a supplement of $0.8 \mathrm{~kg} / \mathrm{d}$ of concentrate mixture pellets $\left(1.75 \mathrm{Mcal}\right.$ of $\mathrm{NE}_{\mathrm{L}} / \mathrm{kg}$ and $16.5 \% \mathrm{CP}$, DM basis) distributed twice daily during milking. Ewes submitted to the WO treatment received half the concentrate $(0.4 \mathrm{~kg} / \mathrm{d})$ in the milking parlor and the other half $(0.4 \mathrm{~kg} / \mathrm{d})$ in the pens.

\section{Procedures, Sample Collection, and Analysis}

Milk yield of individual ewes was recorded weekly (Thursday a.m. and p.m. milkings) from wk 5 to 22 of lactation by using the recording jars in the milking parlor. Milk samples were taken biweekly for analysis of composition $(100 \mathrm{~mL})$ and monthly for SCC $(50 \mathrm{~mL})$. The a.m. and p.m. milk samples were composited, taking into account milk yield at each milking, in a daily sample for composition analysis. Milk samples were preserved with an antimicrobial tablet (Bronopol, Broad Spectrum Micro-tabs II, D\&F Control Systems Inc., San Ramon, CA) and stored at $4^{\circ} \mathrm{C}$ until analysis. Unhomogenized milk samples were analyzed with a nearinfrared spectrometer (InfraAlyzer 450, Bran+Luebbe, Nordersted, Germany) for content of TS, fat, protein $(\mathrm{N} \times 6.38)$, true protein, $\mathrm{CN}$, and lactose, as indicated by Albanell et al. (1999). The SCC was determined in the Dairy Herd Improvement Laboratory of Catalonia (Allic, Cabrils, Barcelona, Spain) by using an automatic cell counter (Fossomatic 5000, Foss Electric, Hillerød, Denmark).

Ewes submitted to the WO treatment in early and mid lactation (groups 1 and 2; Table 2) were used to study the daily effects of omitting 2 milkings per week when applied during early (wk 12) or mid lactation (wk 20). Milk yield and milk composition were individually monitored at each milking to evaluate daily milk changes during the week. Average milk yield and composition for Friday were used as reference values to evaluate the effect of the extended milking intervals on Saturday and Sunday.

Concentrations of $\mathrm{Na}$ and $\mathrm{K}$ in milk and of lactose in plasma were used as indicators of the leakiness of the TJ (Stelwagen et al., 1995, 1997; Castillo et al., 2008a). Milk samples $(10 \mathrm{~mL})$ were frozen at $-20^{\circ} \mathrm{C}$ until being analyzed for $\mathrm{Na}$ and $\mathrm{K}$ contents by inductively coupled plasma atomic emission spectroscopy in the Chemical Analysis Service of the Universitat Autònoma de Barcelona (Bellaterra, Barcelona, Spain). To determine concentrations of plasma lactose, blood samples $(10 \mathrm{~mL})$ were collected daily, just before milking, into heparinized tubes (Venoject, Terumo Europe, Madrid, Spain) by venipuncture of a jugular vein and stored at $4^{\circ} \mathrm{C}$ until centrifugation at $490 \times g$ for $15 \mathrm{~min}$ at room temperature. Plasma was collected and stored at $-20^{\circ} \mathrm{C}$ 
until analyzed for lactose in the Veterinary Clinical Biochemistry Service of the Universitat Autònoma de Barcelona according to the method described by Stelwagen et al. (1994).

\section{Statistical Analyses}

Data were processed by using a mixed-model procedure for repeated measurements (PROC MIXED, version 9.1; SAS Institute Inc., Cary, NC). The model included the fixed effects of breed (Manchega or Lacaune), treatment ( $\mathrm{C}$ or WO), stage of lactation (early or mid lactation), and udder cistern size (large or small); the random effect of the animal; the significant interactions; and the residual error.

To analyze the carryover effects of milking treatments on daily milk yield throughout lactation (wk 8 to 22), another repeated-measurements model that included the fixed effects of breed (Manchega or Lacaune), order of treatment application (C-WO or WO-C, and $\mathrm{C}-\mathrm{C}$ ), and cistern size (large or small); the random effect of the animal; the significant interactions; and the residual error was used.

A third model was used to evaluate the short-term effects of omitting the weekend milkings. The model included the fixed effects of breed (Manchega or Lacaune), experimental week (wk 12 or 20), day (Monday to Sunday), and cistern size (large or small); the random effect of the animal; the significant interactions; and the residual error. Differences between least squares means were determined with the PDIFF option of SAS. Significance was declared at $P<0.05$ unless otherwise indicated. Logarithmic transformations $\left(\log _{10}\right)$ of SCC values were used in the statistical analysis.

\section{RESULTS AND DISCUSSION}

\section{Long-Term Effects on Milk Yield and Composition}

Response to milking omission treatments varied according to breed and the stage of lactation at which they were applied (Figure 1). Application of the WO treatment during early lactation (wk 8 to 14 ) in Manchega ewes tended to decrease daily milk yield $(-15 \%$, $P<0.10$ ) during this period compared with ewes in the $\mathrm{C}$ treatment (Table 3 ), with the difference being a total of $9.2 \mathrm{~L} /$ ewe during the entire early-lactation period $(P=0.07)$. On the contrary, Lacaune ewes, which are known for accommodating milk better than Manchega ewes during extended milking intervals (Castillo et al., 2008b), did not show milk yield losses when WO was performed in early lactation (Table 3 ). This result agreed with their respective cistern sizes, as indicated above. Compared with the C-C group, milk yield values for the C group were similar to those for the WO group $(P>0.05)$ in the Lacaune ewes over the entire lactation (Figure 1), but were similar to the newly created WO group only at mid lactation in the Manchega ewes $(P$ $>0.05$; Figure 1). There is no precedent reporting the absence of milk yield losses when the WO treatment (12 milking/week) is applied in dairy ewes, as was observed in the Lacaune ewes in our results. Huidobro (1988; $-7 \%$ Manchega) and Knight and Gosling (1995; -8\% Poll Dorset) did not observe significant milk yield losses when only 1 milking was omitted weekly, although the daily milk yield of their ewes was low. Milk yield losses of the Manchega ewes in the WO group were in the range of those reported previously when 2 milkings (-24\% Sarda, Casu and Labussière, 1972; -10\% Assaf, Hervás et al., 2006) or 1 milking ( $-13 \%$ Sarda, Casu and Labussière, 1972; -26\% Préalpes du Sud, Labussière et al., 1974a) was omitted weekly.

According to Labussière (1988), dairy trait variations between breeds (i.e., potential of production, mammary morphology, and cisternal capacity) could be one of the main factors responsible for the variable and contradictory results reported in the literature when the effects of milking omission in dairy ruminants are examined. Large mammary cisterns might be capable of storing most of the secreted milk, favoring free drainage of alveolar milk to the cistern during extended milking intervals (Davis et al., 1998), thus avoiding the negative effects on milk secretion caused by the TJ opening (Stelwagen et al., 1995), which occurs from $20 \mathrm{~h}$ of milk accumulation in dairy ewes (Castillo et al., 2008a), and also avoiding the increase in concentration of serotonin in the mammary gland (Stull et al., 2007; Hernández et al., 2008).

Milk yield was affected by cistern size in Manchega ewes $(\mathrm{r}=0.49, P<0.01)$ and tended to do so $(\mathrm{r}=$ $0.51, P=0.07)$ in Lacaune ewes. Castillo et al. (2008b) and Rovai et al. (2008) also reported a positive correlation $(\mathrm{r}=0.48$ to 0.87$)$ between milk yield and cistern size in dairy ewes. Effects of a cistern size $\times$ treatment interaction on milk yield were not significant in the first $(P=0.79)$ and second $(P=0.87)$ experimental periods (data not shown), so large- and small-cisterned ewes seemed to respond similarly to the WO treatment throughout the experimental period. Nevertheless, this lack of response would have been conditioned by the time that elapsed between the milking omissions (Saturday to Sunday) and the test day (Thursday). Further discussion of the effect of cisternal size on milk losses is included in the short-term effects section below.

In contrast, implementation of the WO treatment during mid lactation (wk 15 to 22) did not significantly affect milk yield in either breed (Figure 1 and Table 3), indicating that the effects of milking omission become 


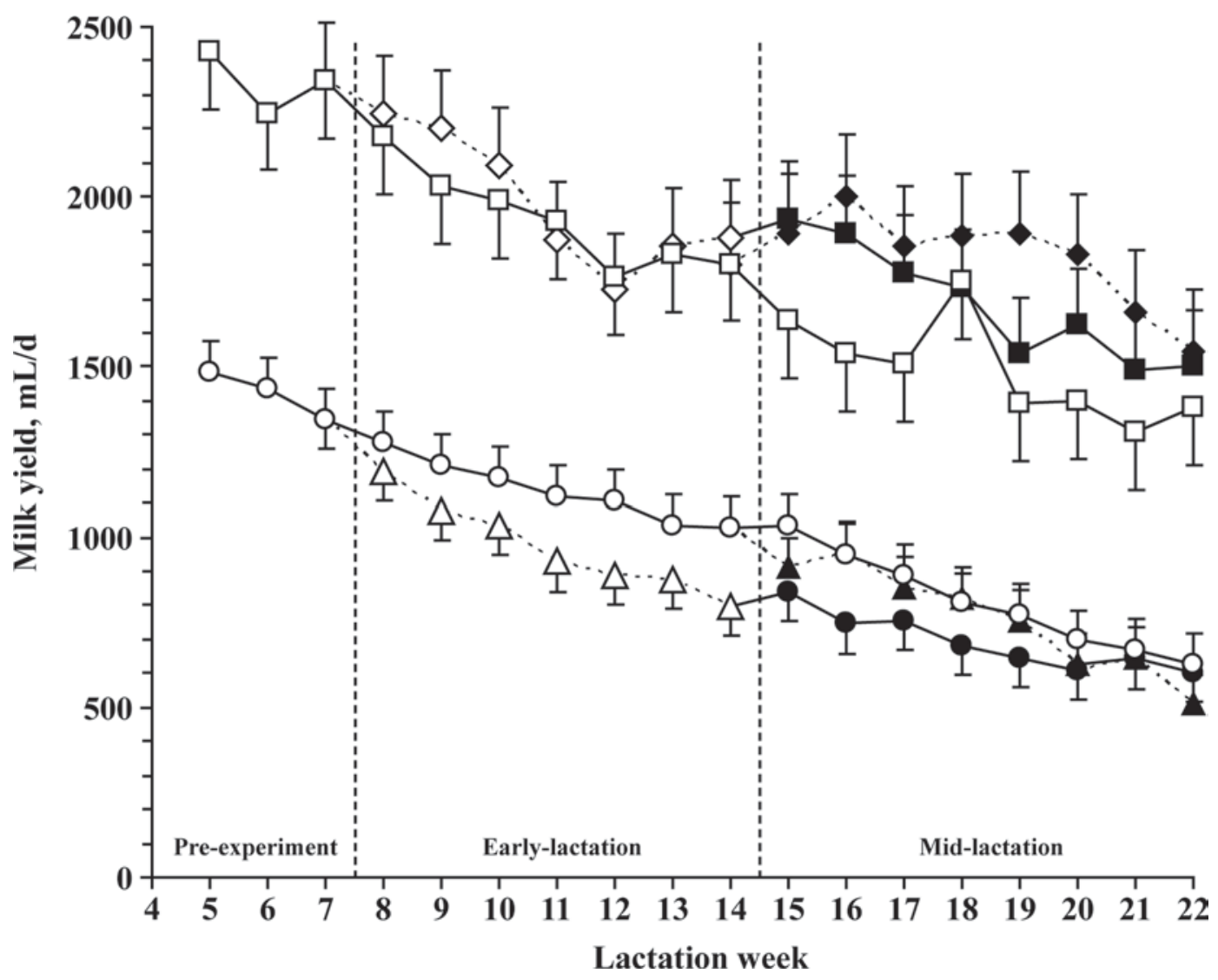

Figure 1. Effect of milking schedule treatment (control 14 milkings/wk: $\square, \mathbf{\square}, \bigcirc$, $\mathbf{\bullet}$; weekend omitted 12 milkings/wk: $\Delta, \mathbf{\Delta}, \diamond, \bullet$ ) during early and mid lactation in Manchega $(\triangle, \boldsymbol{\Lambda}$ and $\bigcirc, \bullet)$ and Lacaune $(\diamond, \bullet$ and $\square, \boldsymbol{\square})$ ewes on daily milk yield throughout the experiment. Dotted lines indicate the beginning of weekend omission treatments in early and mid lactation. From mid lactation, open symbols correspond to the permanent control group, whereas solid symbols correspond to groups in which weekend omissions were applied either in early or mid lactation. Values are least squares means. Vertical bars represent standard errors of the means.

less noticeable as lactation progresses in ewes (Knight and Gosling, 1995). Omitting 1 milking per week in dairy cows hardly affected milk yield in mid lactation (Ayadi et al., 2003; $-3.7 \%$ ) and did not affect it in late lactation (O'Brien et al., 2002).

Regarding lactation persistency, responses to the WO treatment varied according to breed and the stage of lactation at which it was applied (Table 3). Thus, lactation persistency in Manchega ewes was negatively affected $(P<0.05)$ by the WO treatment in early lactation, whereas it was not affected during mid lactation. The mean milk yield decline in Lacaune ewes did not vary by treatment in either early or mid lactation, in agreement with the observations of Hervás et al. (2006) in Assaf ewes.

Milk composition (Table 3$)$ varied by breed $(P<$ $0.01)$ and stage of lactation $(P<0.05)$, except for whey proteins, but the WO treatment did not affect milk composition in either Manchega or Lacaune ewes throughout the lactation. Our results agree with those reported for Sarda and Assaf ewes submitted to 1 milk- ing omission weekly (Casu and Labussière, 1972; Hervás et al., 2006), but disagree with those of Labussière et al. (1974a) and Huidobro (1988), who reported an increase in milk fat content in Préalpes du Sud and Manchega ewes, respectively. Moreover, an increase in milk fat was reported in Assaf ewes (Hervás et al., 2006) when 2 milkings per week were omitted.

In our study, the WO treatment did not affect $(P>$ $0.05)$ fat, protein, and lactose yields in milk in either early or mid lactation in either breed (data not shown). Nevertheless, the numerically lower milk yield in early lactation for Manchega ewes in the WO treatment tended to result in lower yields of milk fat $(75 \pm 6$ vs. $59 \pm 7 \mathrm{~g} / \mathrm{d} ; P=0.06)$ and milk protein $(62 \pm 4$ vs. 50 $\pm 5 \mathrm{~g} / \mathrm{d} ; P=0.07)$ for ewes in the WO and $\mathrm{C}$ treatment, respectively.

Breed, stage of lactation, and WO treatment did not affect SCC in milk (Table 3; $P>0.05$ ), with $\log _{10} \mathrm{SCC}$ on average being 4.99 in early lactation and 5.07 in mid lactation. Although Davis et al. (1999), in Holstein cows, and Nudda et al. (2002), in Sarda ewes, reported 
Table 3. Lactational performance of dairy ewes according to weekly milking schedule [control (C), 14 milkings/wk; weekend omitted (WO), 12 milkings/wk), breed, and stage of lactation ${ }^{1}$

\begin{tabular}{|c|c|c|c|c|c|c|c|c|}
\hline Item & \multicolumn{4}{|c|}{ Early lactation } & \multicolumn{4}{|c|}{ Mid lactation } \\
\hline \multicolumn{9}{|c|}{ Milk yield, L/d } \\
\hline Lacaune & 1.98 & 2.01 & 0.18 & 0.88 & 1.82 & 1.66 & 0.16 & 0.34 \\
\hline \multicolumn{9}{|c|}{ Persistency, ${ }^{3} \% /$ wk } \\
\hline Manchega & 94.0 & 98.0 & 1.8 & 0.02 & 93.4 & 95.3 & 2.8 & 0.50 \\
\hline \multicolumn{9}{|c|}{ Fat } \\
\hline Manchega & 6.61 & 7.02 & 0.21 & 0.06 & 7.62 & 7.74 & 0.28 & 0.66 \\
\hline Lacaune & 5.86 & 6.16 & 0.24 & 0.29 & 5.79 & 6.01 & 0.21 & 0.30 \\
\hline \multicolumn{9}{|l|}{ Protein } \\
\hline Manchega & 5.59 & 5.72 & 0.16 & 0.16 & 6.15 & 6.22 & 0.28 & 0.80 \\
\hline Lacaune & 4.80 & 5.06 & 0.22 & 0.33 & 5.08 & 5.10 & 0.24 & 0.93 \\
\hline \multicolumn{9}{|l|}{$\mathrm{CN}$} \\
\hline \multicolumn{9}{|l|}{ Lactose } \\
\hline Manchega & 4.72 & 4.72 & 0.07 & 0.99 & 4.67 & 4.59 & 0.05 & 0.08 \\
\hline Lacaune & 4.56 & 4.59 & 0.06 & 0.57 & 4.47 & 4.42 & 0.06 & 0.41 \\
\hline \multicolumn{9}{|l|}{ TS } \\
\hline Manchega & 17.94 & 18.60 & 0.35 & 0.07 & 19.62 & 19.95 & 0.51 & 0.52 \\
\hline Lacaune & 16.47 & 17.01 & 0.44 & 0.32 & 16.68 & 16.97 & 0.36 & 0.44 \\
\hline \multicolumn{9}{|c|}{$\mathrm{SCC}, \log _{10} / \mathrm{mL}$} \\
\hline Manchega & 5.20 & 4.97 & 0.15 & 0.15 & 5.03 & 5.05 & 0.13 & 0.86 \\
\hline Lacaune & 4.78 & 5.00 & 0.40 & 0.55 & 5.08 & 5.09 & 0.86 & 0.98 \\
\hline
\end{tabular}

${ }^{1}$ Values are least squares means.

${ }^{2}$ Standard error of the difference.

${ }^{3}$ Lactation persistency was calculated by dividing the amount of milk produced in week $\mathrm{n}$ by the amount of milk produced in wk $\mathrm{n}-1$, on average, for early lactation (wk 8 to 14 ) and mid lactation (wk 15 to 22).

an increase in SCC in response to a reduction in the number of milkings, this result was not supported by other studies conducted in cows (O'Brien et al., 2002; Ayadi et al., 2003), goats (Salama et al., 2003), or ewes (Labussière et al., 1974a; Huidobro, 1988; Hervás et al., 2006), which agrees with our results.

\section{Short-Term Effects on Milk Yield and Composition}

Milk Yield and Milk Secretion Rate. Daily milk yields during wk 12 (early lactation) and wk 20 (mid lactation) are shown in Figure 2. Regarding early lactation and compared with the previous Friday's milk yield (Manchega, 0.90 L/d; Lacaune, 1.75 L/d), Saturday and Sunday milk yields decreased by $24 \%$ in Manchega ewes $(P<0.05)$ and by $18 \%$ in Lacaune ewes $(P<0.05)$ because of the milking omissions. Nevertheless, when the twice-daily milking frequency was restored on Monday, daily milk yield increased markedly in Manchega ewes $(20 \% ; P<0.05)$ and in Lacaune ewes $(27 \% ; P<$ 0.05), compensating for milk yield losses in the WO treatment, partly in Manchega and totally in Lacaune ewes. Reported compensatory increases after weekend milking omissions have varied according to species, breed, and number of omitted milkings, as observed in 1 milking omitted weekly in Sarda (89\%; Casu and Labussière, 1972), Préalpes du Sud (46\%; Labussière et al., 1974a), and Assaf ewes (27\%; Hervás et al., 2006) and in Holstein cows (9\%; Ayadi et al., 2003), or in 2 milkings omitted weekly in Assaf ewes (16\%; Hervás et al., 2006).

The compensatory increase after milking omissions in our results (Figure 3$)$ varied by breed $(P<0.001)$ and correlated positively with cisternal size $(P<$ 0.05 ). The Sunday to Monday milk yield increased in large-cisterned Manchega ewes $(32 \%, P<0.05)$ and was greater in large-cisterned $(29 \%, P<0.05)$ and small-cisterned Lacaune ewes $(29 \%, P<0.05)$ than in small-cisterned Manchega ewes $(4 \%, P>0.05)$. Smallcisterned ewes have a limited milk storage capacity in their cisterns, so when milking omission and extended milking intervals are practiced, intramammary pressure increases (Peaker, 1980), alveolar drainage decreases (Davis et al., 1998; Stelwagen, 2001), and mammary 


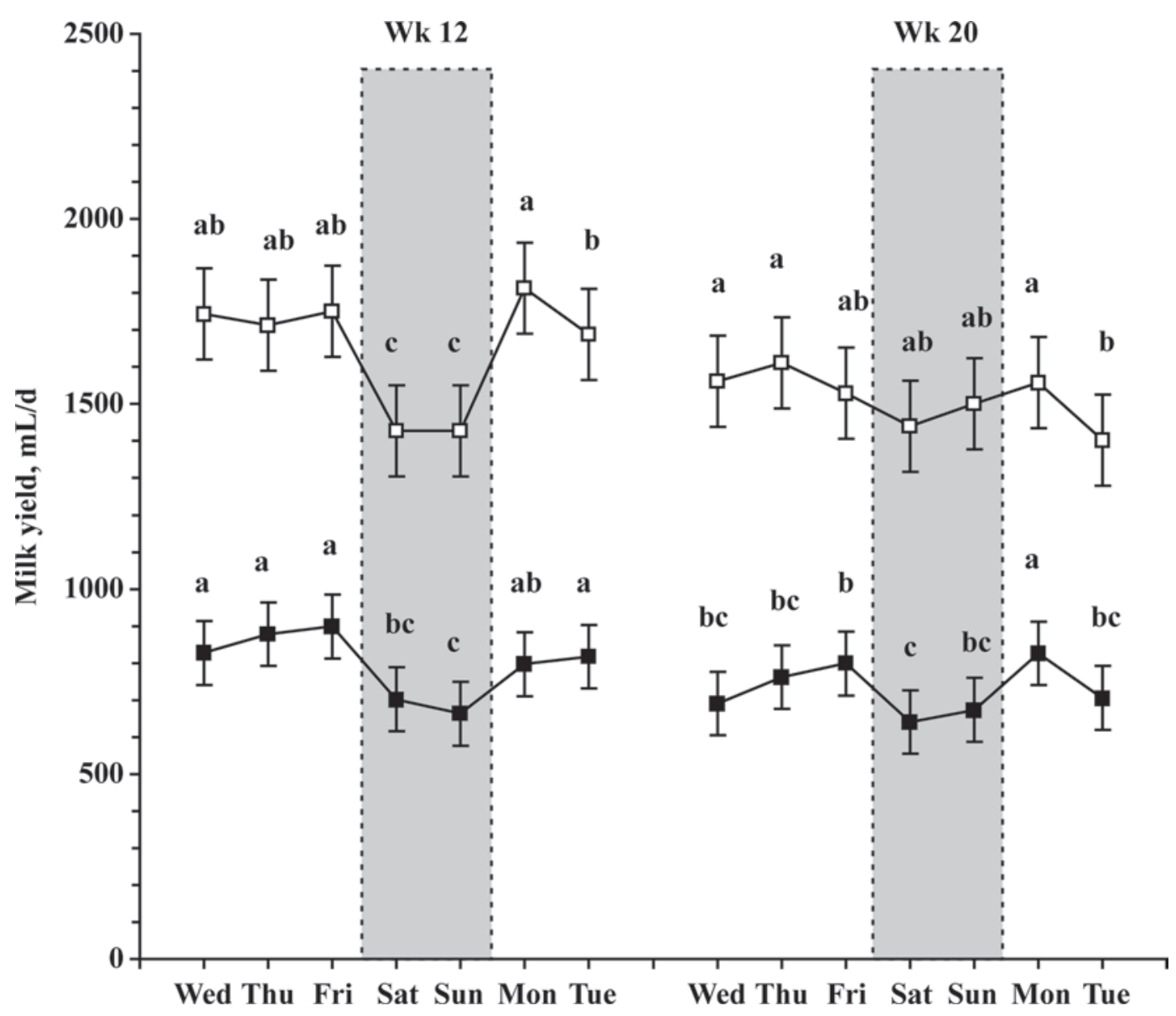

Figure 2. Effect of milking omissions (Saturday and Sunday) on daily milk yield during wk 12 and 20 of lactation in Manchega (匚) and Lacaune $(\square)$ dairy ewes. Values are least squares means. Vertical bars represent standard errors of the means. ${ }^{\text {a-c }}$ Means within a breed and week without a common letter are different $(P<0.05)$.

TJ permeability increases (Stelwagen, 2001; Castillo et al., 2008a), all of which negatively affect milk secretion and, consequently, daily milk yield. Large-cisterned udders are more elastic and adapt better to longer milking intervals.

On average, the calculated milk secretion rate varied when the WO treatment was performed in early lactation, decreasing from Friday ( 38 and $73 \mathrm{~mL} / \mathrm{h}$ ) to Saturday and Sunday (31 and $65 \mathrm{~mL} / \mathrm{h}$ ) in Manchega and Lacaune ewes, respectively. The decrease in milk secretion rate lasted until Tuesday in both breeds, indicating that mammary epithelial cells did not recover immediately after restoring the twice-daily milking frequency.

Practicing the WO treatment at mid lactation caused less noticeable effects during the week than at early lactation in dairy ewes (Figure 2). No daily effects of the WO treatment on milk yield were observed at mid lactation in Lacaune ewes $(P>0.05)$. Although daily milk yield losses $(-20 \%, P<0.05)$ were observed in Manchega ewes during the milking omission days (Saturday and Sunday), milk yield was completely recovered on Monday $(+23 \%, P<0.05)$ in small- and large-cisterned ewes (Figure 3). Moreover, our results suggest that at advanced stages of lactation, mammary cistern size does not play such an essential role in milk yield maintenance as it plays at stages closer to the peak. Small mammary cisterns, as defined in our study in dairy sheep, seem to be large enough to store secreted milk during extended milking intervals in mid lactation, thereby avoiding the deleterious effects of milk stasis within the alveoli (Peaker and Blatchford, 1988).

Fat and Protein in Milk. Weekly omission of 2 milkings had a greater effect on milk fat percentage than on milk protein percentage (Figure 4). As observed in this study, others have shown that an increase in the milking interval decreases milk fat content in dairy ewes (McKusick et al., 2002; Castillo et al., 2008a). 


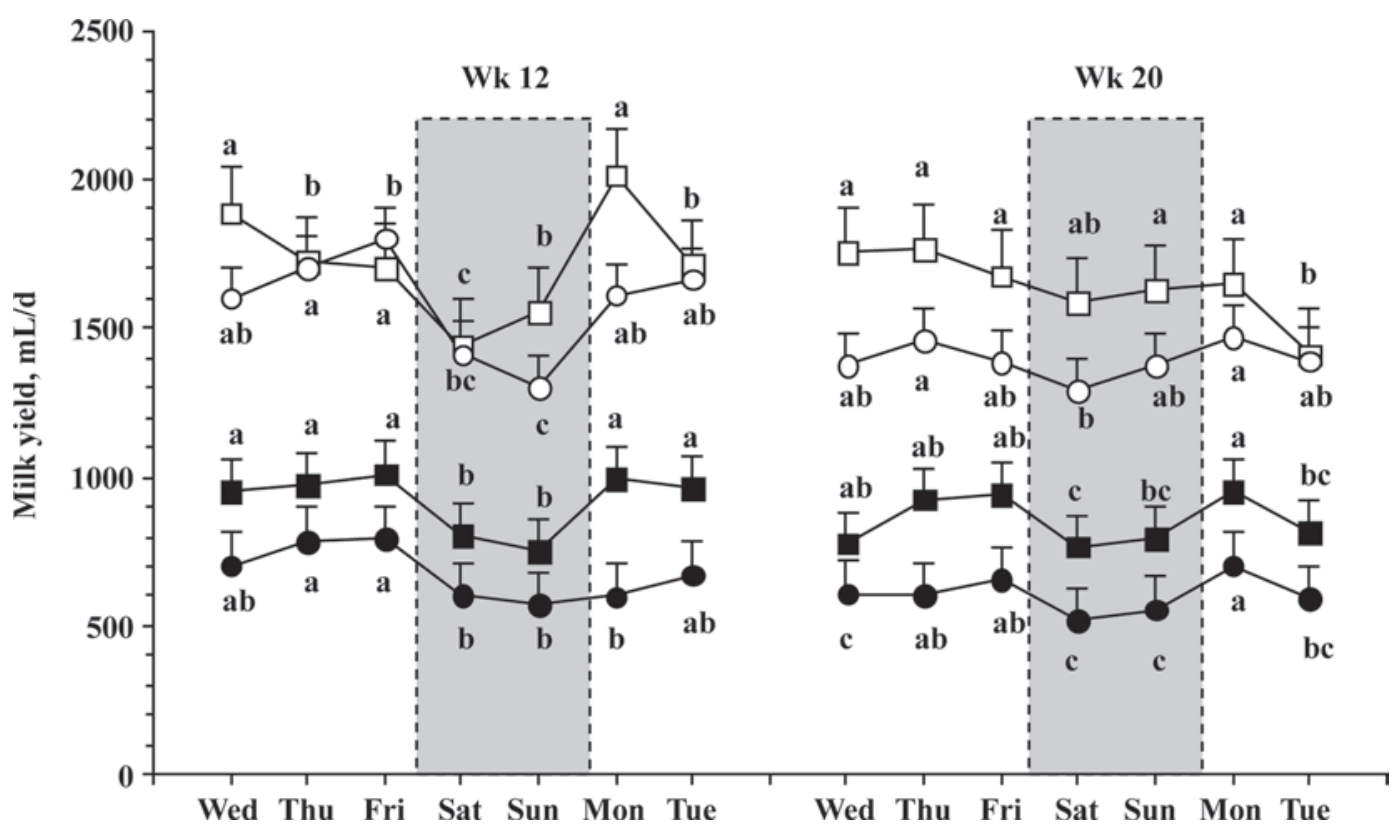

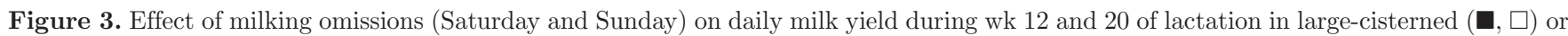
small-cisterned $(\bullet, \bigcirc)$ Manchega (solid symbols) and Lacaune (open symbols) dairy ewes. Values are least squares means. Vertical bars represent standard errors of the means. ${ }^{\mathrm{a}-}$ Means within a breed, week, and cistern size without a common letter are different $(P<0.05)$.

Compared with the Friday milk fat content values (Manchega, 5.89 and 7.28\%; Lacaune, 5.37 and 4.98\%; early and mid lactation, respectively) Saturday values decreased by $13 \%(P<0.05)$ in early lactation in both breeds, and by $13 \%(P<0.05)$ in Manchega ewes and $7 \%(P>0.10)$ in Lacaune ewes in mid lactation. On Sunday, although the milking interval $(22 \mathrm{~h})$ was similar to that applied on Saturday, milk fat content increased and recovered the Friday value, reaching its maximum content on Monday (Manchega, 7.57 and 8.60\%; Lacaune, 6.56 and $6.29 \%$; early and mid lactation, respectively). Extended milking intervals in dairy sheep favor the accumulation of fat in the alveolar compartment (McKusick et al., 2002; Castillo et al., 2008b), causing an increase of fat content in the residual milk. This high-fat residual milk, which was recovered in our case after $22 \mathrm{~h}$ (Sunday) and $18 \mathrm{~h}$ (Monday) of the milking interval, may have contributed to the dramatic milk fat increase observed on those days. After returning to the twice-daily milking routine, fat content in the residual milk should have recovered to its habitual levels, and therefore to the habitual milk fat content in total machine milk. The obtained values in milk fat content were in agreement with those reported by Casu and Labussière (1972) and Labussière et al. (1974a) in ewes submitted to a Sunday evening milking omission.

In contrast, milk protein content in our results was less affected by milking omission than was milk fat content, in agreement with the results of Casu and
Labussière (1972) and Labussière et al. (1974a) in ewes submitted to a Sunday evening milking omission. Thus, milk protein content was not affected by the WO treatment in Lacaune ewes at any stage of lactation but was moderately increased in Manchega ewes $(7 \%, P<0.05)$ in early lactation.

Lactose, Na, and $\mathrm{K}$ in Milk, and TJ Permeability. Extended milking intervals favor mammary TJ opening, which allows lactose and other milk components to leak out of the alveolar compartment to the blood, and vice versa (Stelwagen, 2001). In our study, the values of lactose in milk (Figure 5) tended to be higher in Manchega than in Lacaune ewes at early lactation $(P=0.06)$ but they did not differ at mid lactation $(P=0.23)$, as reported previously by Castillo et al. (2008b). Daily lactose content in the milk tended to decrease in both breeds in early lactation because of the WO treatment (Figure 5). Extended milking intervals (18 and $22 \mathrm{~h}$ ) were applied on Saturday, Sunday, and Monday in the WO treatment. Although habitual milking frequency had already been recovered on Monday, milk lactose content decreased $(5 \%, P<0.01)$ from Friday to Saturday in Manchega ewes in early lactation, and did not reach the Friday $(4.6 \%)$ value until Tuesday. The mammary TJ seemed to keep opening until the day after the last milking omission, from which we inferred that the mammary TJ needed time to adapt to the changes in milking frequency. 
Milk lactose content in Manchega ewes showed only a tendency to decrease $(P=0.11)$ in mid lactation. Milk lactose content in Lacaune ewes did not decrease from Friday to Saturday in early lactation $(P=0.18)$ but did decrease in mid lactation $(7 \%, P<0.05)$.

Lactose concentration in plasma was used as an indicator of the state of the TJ (Figure 5), as proposed by Stelwagen et al. (1994) and as used previously by Castillo et al. (2008a) in sheep. Milking omissions in early lactation significantly affected plasma lactose concentration in both breeds, which dramatically increased from Friday to Saturday (Manchega, 73\%; Lacaune,
$85 \% ; P<0.01)$ and with these high values maintained until Sunday in both breeds. These results confirm the leaky state of TJ in the mammary epithelium when extended milking intervals were applied at early lactation, in agreement with the report by Castillo et al. (2008a) in the same sheep breeds. In our study, high plasma lactose concentrations at early lactation were also obtained on Sunday; thus, plasma lactose concentration peaked each time a milking was omitted. The Sunday plasma lactose peak was numerically lower than that on Saturday, and was numerically greater than that before applying the WO treatment. Attenuation of the
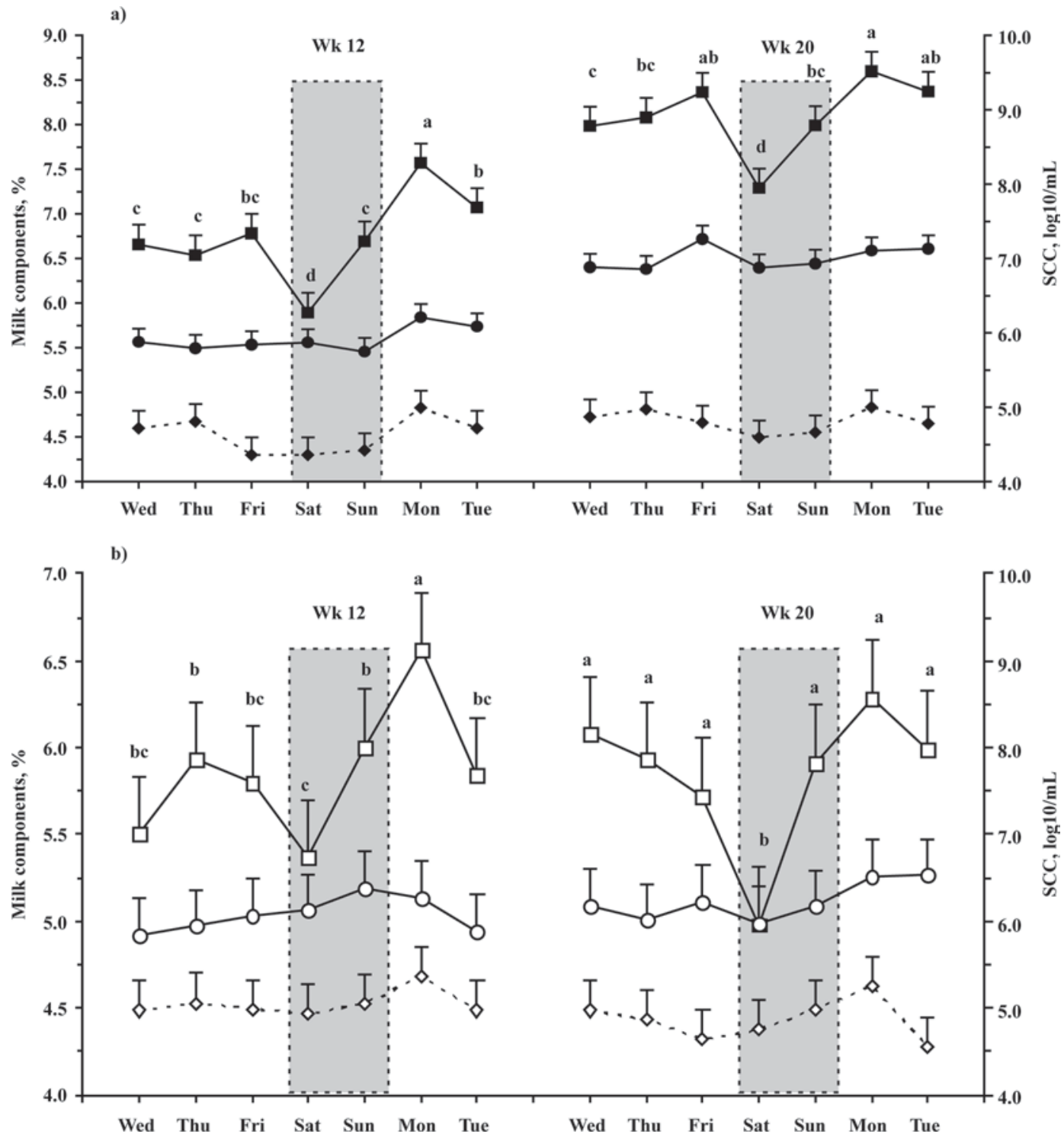

Figure 4. Effect of milking omissions (Saturday and Sunday) on daily milk fat $(\mathbf{\square}, \square)$ and milk protein $(\boldsymbol{\bullet}, \bigcirc)$ contents, and on the daily $\operatorname{SCC}(\diamond, \diamond)$ content in milk during wk 12 and 20 of lactation in Manchega (a, solid symbols) and Lacaune (b, open symbols). Values are least squares means. Vertical bars represent standard errors of the means. ${ }^{\mathrm{a}-\mathrm{d}}$ Means within a breed, week, and trait without a common letter are different $(P<0.05)$ 


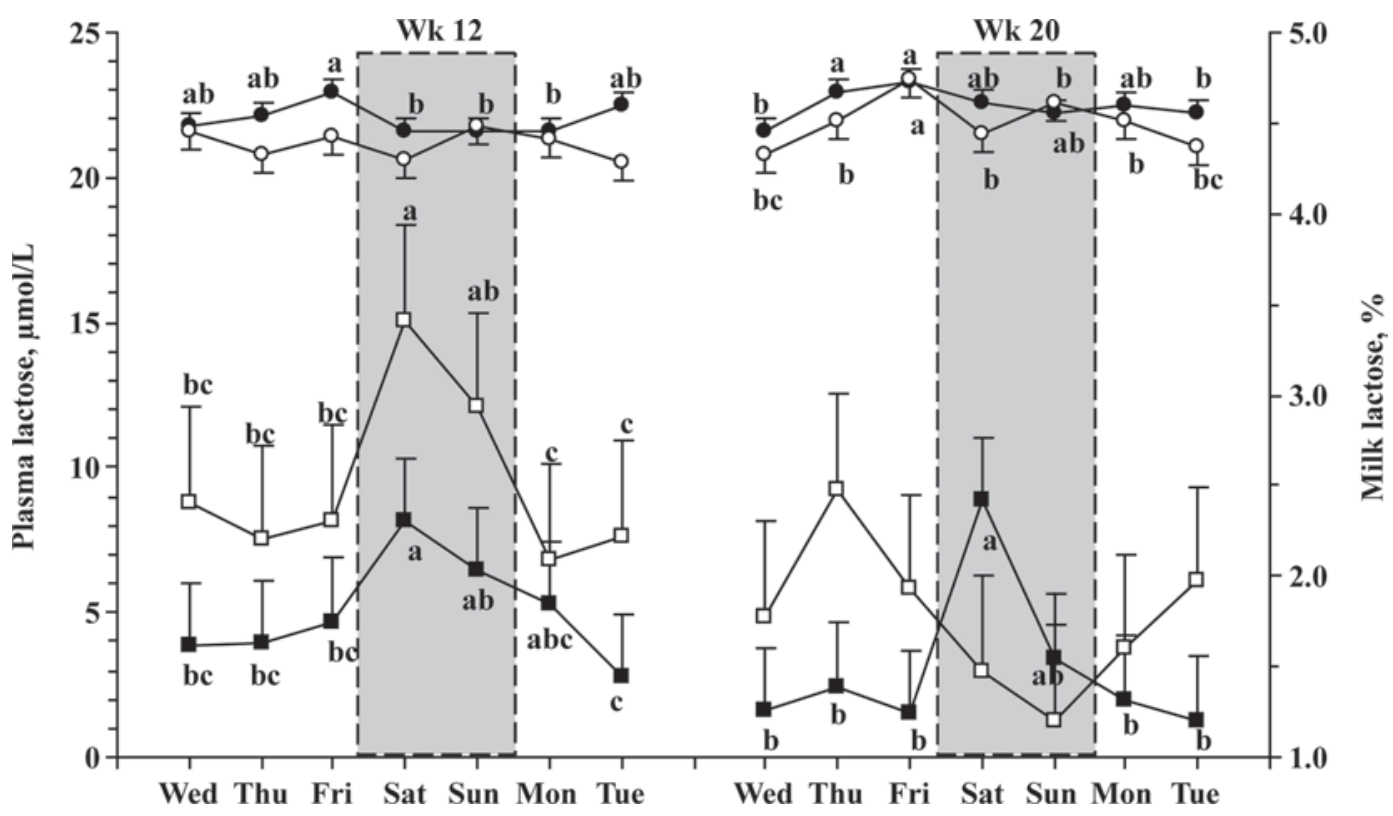

Figure 5. Effect of milking omissions (Saturday and Sunday) on daily milk lactose content $(\bullet, 0)$ and daily concentration of plasma lactose , $\square$ ) during wk 12 and 20 of lactation in Manchega (solid symbols) and Lacaune (open symbols). Values are least squares means. Vertical bars represent standard errors of the means. ${ }^{a-c}$ Means within a breed, week, and trait without a common letter are different $(P<0.05)$.

response to the WO treatment supported the idea that the mammary TJ adapted to extended milking intervals in dairy ewes when applied successively, as reported previously in dairy cows (Stelwagen et al. 1997).

Stelwagen et al. $(1995,1997)$ reported that plasma lactose levels declined rapidly after removing the milk lactose during milking, suggesting that leaking TJ close rapidly after milking. In our results, Manchega and Lacaune ewes showed the lowest plasma lactose levels after the habitual twice-daily milking routine was restored (Monday), indicating that TJ also close rapidly after a short milking interval in dairy ewes.

In mid lactation, the response pattern of plasma lactose to the WO treatment in Manchega ewes was similar to that observed previously in early lactation (Figure $5)$. Despite the milk lactose changes in mid lactation discussed previously (Figure 5), the large variation in plasma lactose values reported in Lacaune ewes during mid lactation may have contributed to making their response pattern not significant $(P>0.05)$. These different responses to a milking omission according to breed might be explained by the fact that Lacaune sheep have larger udder cisterns and are more tolerant of milk accumulation between milkings than are Manchega sheep (Castillo et al., 2008a; Rovai et al., 2008).

Daily variation of $\mathrm{Na}$ and $\mathrm{K}$ concentrations in milk and the Na:K ratio attributable to the WO treatment are shown in Figure 6. In early lactation, Na responded to the Saturday milking omission by an increase $(P$ $<0.05)$ in $\mathrm{Na}$ concentration in milk, which remained steady until Wednesday in both breeds; Friday values were recovered on Thursday. In contrast, milk K concentration decreased with the WO treatment, showing the lowest $(P<0.05)$ values from Saturday to Monday in both breeds. In mid lactation, no variations were detected in Na concentration in either breed $(P>0.05)$, but $\mathrm{K}$ concentration behaved as it had done in early lactation, also showing the lowest $(P<0.05)$ values on Sunday and Monday. Our results confirmed that milking omission on Saturday and Sunday (22-h milking interval) caused mammary TJ destabilization, and thus changes in the ionic milk composition. In dairy ewes, the TJ opening is described as occurring after $20 \mathrm{~h}$ of udder filling (Castillo et al., 2008a).

The Na:K ratio increased $(P<0.001)$ in early lactation and tended $(P=0.09)$ to do so in mid lactation because of the WO treatment, and Friday values were restored on Tuesday. Stelwagen et al. (1999) reported that an increase in the Na:K ratio caused a transient reduction in milk secretion. Thus, the increase in Na:K ratio in milk observed in our experiment may at least partially explain the reduction in milk secretion; consequently, the reduction in milk yield shown during the days milking was omitted, especially in early lactation.

Milk $\boldsymbol{S C C}$. Ewes were free of clinical mastitis and showed low $\log _{10}$ SCC during the experimental weeks (Figure 4): wk 12 (Manchega, $4.62 \pm 0.18 \log _{10}$ cells/ $\mathrm{mL}$; Lacaune, $5.04 \pm 0.26 \log _{10}$ cells $/ \mathrm{mL}$ ) and wk 20 (Manchega, $4.80 \pm 0.09 \log _{10}$ cells $/ \mathrm{mL}$; Lacaune, 4.86 $\pm 0.13 \log _{10}$ cells $/ \mathrm{mL}$ ). The lowest $\mathrm{SCC}$ was observed 


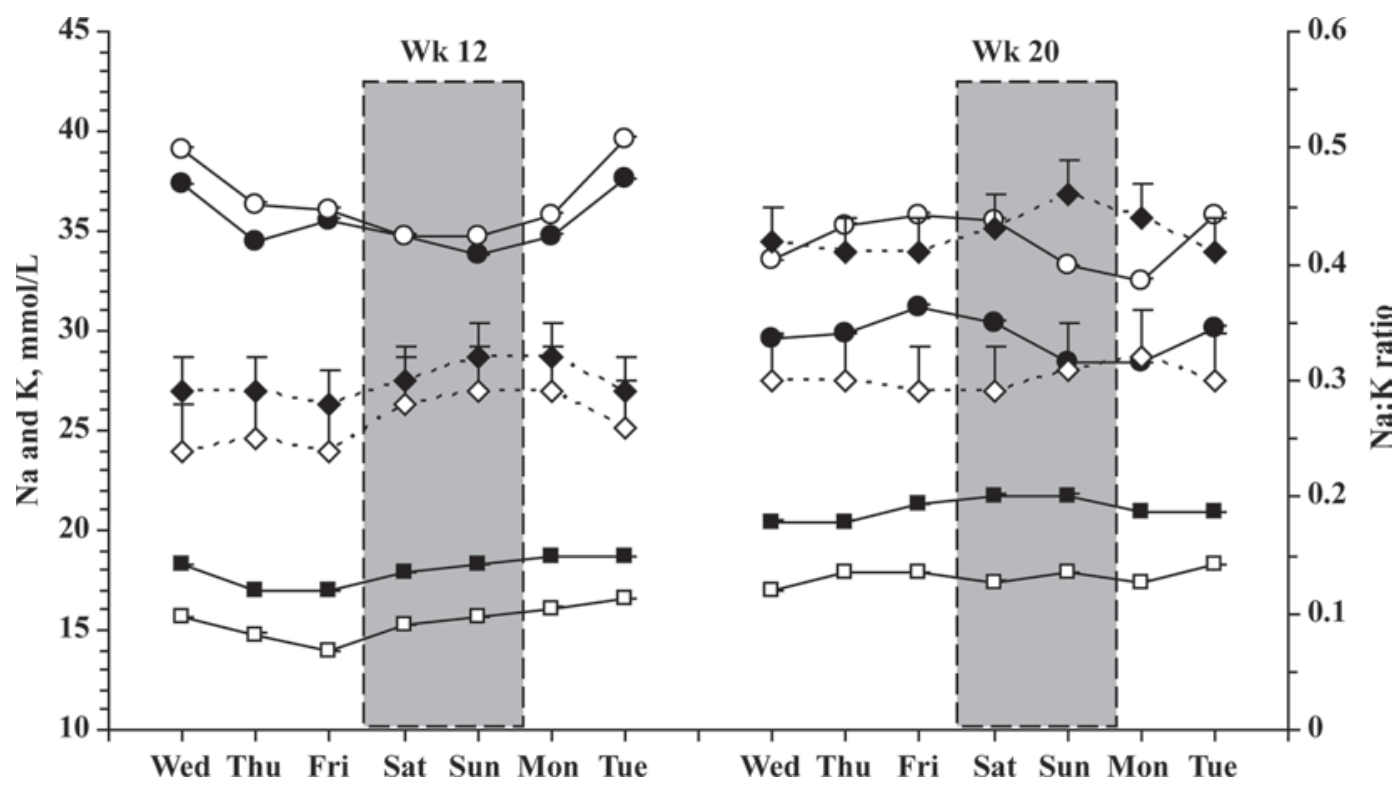

Figure 6. Effect of milking omissions (Saturday and Sunday) on daily concentration of $\mathrm{Na}(\boldsymbol{\square}, \square)$ and $\mathrm{K}(\boldsymbol{\bullet}, \mathrm{O})$, and on the Na:K ratio (• $\diamond)$ in milk during wk 12 and 20 of lactation in Manchega (solid symbols) and Lacaune (open symbols). Values are least squares means. Vertical bars represent standard errors of the means.

during the days of milking omission because of a dilution effect. After restoring the twice-daily milking frequency, SCC increased markedly $(P<0.05)$, reaching values similar to those on Friday (Figure 4). No studies exist on daily SCC changes after applying the WO treatment in dairy ewes. In dairy cows, Ayadi et al. (2003) reported increases in SCC after omitting 1 milking per week, but the SCC decreased again after 4 milkings and no clinical mastitis was observed in any cow at any time.

\section{CONCLUSIONS}

Omitting 2 milkings weekly may be an interesting management approach for reducing farm labor, with minor effects on milk yield and no negative effects on milk composition and SCC values in healthy dairy ewes. Milk yield losses caused by milking omission depended on the udder cistern size and stage of lactation. Largecisterned ewes adapted to 2 milking omissions per week without milk yield losses both in early lactation and in mid lactation. Small-cisterned ewes reduced their losses in milk yield when weekend milking omissions began at mid lactation.

In addition, this study showed that milk fat content increased markedly after milking omissions in dairy ewes, with normal values recovered $48 \mathrm{~h}$ after the last milking omission. No relevant changes were observed in other cheese-yielding milk components. Moreover, the mammary TJ switched rapidly to a leaky state when milking was omitted, and it returned again to a closed state after the twice-daily milking routine was restored. Milk recording should be conducted in the middle of the week to avoid milk component variations caused by milking omissions and the associated mammary TJ leakiness. Our results also suggest that once-daily milking may be possible in some dairy sheep breeds for long periods during lactation.

\section{ACKNOWLEDGMENTS}

This work is part of a Comisión Interministerial de Ciencia y Tecnología research project (AGL200203472) of the Spanish Ministry of Science and Technology (Madrid). The authors are grateful to Ramon Costa and the team of the S1GCE (Servei de Granges i Camps Experimentals) of the Universitat Autònoma de Barcelona for the care of the animals and to Nic Aldam for the English revision of the manuscript.

\section{REFERENCES}

Albanell, E., P. Cáceres, G. Caja, E. Molina, and A. Gargouri. 1999. Determination of fat, protein, and total solids in ovine milk by near-infrared spectroscopy. J. AOAC 82:753-758.

Ayadi, M., G. Caja, X. Such, and C. H. Knight. 2003. Effect of omitting one milking weekly on lactational performances and morphological udder changes in dairy cows. J. Dairy Sci. 86:2352-2358.

Castillo, V., X. Such, G. Caja, R. Casals, E. Albanell, and A. A. K. Salama. 2008a. Effect of milking interval on milk secretion and mammary tight junction permeability in dairy ewes. J. Dairy Sci. 91:2610-2619.

Castillo, V., X. Such, G. Caja, A. A. K. Salama, E. Albanell, and R. Casals. 2008b. Changes in alveolar and cisternal compartments induced by milking interval in the udder of dairy ewes. J. Dairy Sci. 91:3403-3411. 
Casu, S., and J. Labussière. 1972. Premiers résultats concernant la suppression d'une ou plusieurs traits par semaine chez la brebis Sarde. Ann. Zootech. 21:223-232.

Davis, S. R., V. C. Farr, P. J. A. Copeman, V. R. Carruthers, C. H. Knight, and K. Stelwagen. 1998. Partitioning of milk accumulation between cisternal and alveolar compartments of the bovine udder: Relationship to production loss during once daily milking. J. Dairy Res. 65:1-8.

Davis, S. R., V. C. Farr, and K. Stelwagen. 1999. Regulation of yield loss and milk composition during once-daily milking: A review. Livest. Prod. Sci. 59:77-94.

Gallego, L., M. P. Molina, A. Torres, and G. Caja. 1984. Influencia de la supresión de uno o varios ordeños sobre la producción de leche en ovejas de raza Manchega. Pages 1-25 in I Jornadas Ganaderas de Castilla-La Mancha, Toledo. Monografías Castilla-La Mancha No. 1, Servicio de Publicaciones de la Junta de Comunidades de Castilla-La Mancha, Toledo, Spain.

Hernández, L. L., C. M. Stiening, J. B. Wheelock, L. H. Baumgard, A. M. Parkhurst, and R. J. Collier. 2008. Evaluation of serotonin as a feedback inhibitor of lactation in the bovine. J. Dairy Sci. 91:1834-1844.

Hervás, G., J. L. Ramella, S. López, J. S. González, and A. R. Mantecón. 2006. Effect of omitting one or two milkings weekly on lactational performance in dairy ewes. J. Dairy Res. 73:207-215.

Huidobro, F. 1988. Effects of suppressing Sunday afternoon milking in Manchega sheep. Inf. Técn. Econ. Agrar. Prod. Anim. 78:33-37.

Knight, T. W., and L. S. Gosling. 1995. Effects of milking frequency and machine-stripping on the yield and composition of milk from Poll Dorset ewes. N. Z. J. Agric. Res. 38:123-130.

Labussière, J. 1988. Review of physiological and anatomical factors influencing the milking ability of ewes and the organization of milking. Livest. Prod. Sci. 18:253-274.

Labussière, J., and J. Coindet. 1968. Effets de la suppression de la traite du dimanche soir, chez les bovines de race Française Frisonne Pie Noire. Ann. Zootech. 17:231-244.

Labussière, J., J. F. Combaud, and P. Petrequin. 1974a. Effets de la suppression de la traite du dimanche soir sur les brebis de race Préalpes du Sud. Ann. Zootech. 23:435-444.

Labussière, J., J. F. Combaud, and P. Petrequin. 1974b. Influence de la fréquence des traites et des tétées sur la production laitière des brebis Préalpes du sud. Ann. Zootech. 23:445-457.

Le Mens, P. 1978. La suppression de la traite du dimanche soir chez la chèvre: Conséquences sur la production laitière et la composition du lait. Pages 277-287 in Proc. 2nd Int. Symp. Milking Small Rumin., Alghero, Italy. Istituto Zootecnico e Caseario per la Sardegna, Sassari, Italy.

McKusick, B. C., D. L. Thomas, Y. M. Berger, and P. G. Marnet. 2002. Effect of milking interval on alveolar versus cisternal milk accumulation and milk production and composition in dairy ewes. J. Dairy Sci. 85:2197-2206.

Nudda, A., R. Bencini, S. Mijatovic, and G. Pulina. 2002. The yield and composition of milk in Sarda, Awassi, and Merino sheep milked unilaterally at different frequencies. J. Dairy Sci. 85:2879-2884.

O'Brien, B., G. Ryan, W. J. Meaney, D. McDonagh, and A. Kelly. 2002. Effect of frequency of milking on yield, composition and processing quality of milk. J. Dairy Res. 69:367-374.

Papachristoforou, C., A. Roushias, and A. P. Mavrogenis. 1982. The effect of milking frequency on the milk production of Chios ewes and Damascus goats. Ann. Zootech. 31:37-46.

Peaker, M. 1980. The effect of raised intramammary pressure on mammary function in the goat in relation to the cessation of lactation. J. Physiol. 301:415-428.

Peaker, M., and D. R. Blatchford. 1988. Distribution of milk in the goat mammary gland and its relation to the rate of control of milk secretion. J. Dairy Res. 55:41-48.

Rovai, M., G. Caja, and X. Such. 2008. Evaluation of udder cisterns and effects on milk yield of dairy ewes. J. Dairy Sci. 91:4622 4629.

Salama, A. A. K., X. Such, G. Caja, M. Rovai, R. Casals, E. Albanell, M. P. Marín, and A. Martí. 2003. Effects of once versus twice daily milking throughout lactation on milk yield and milk composition in dairy goats. J. Dairy Sci. 86:1673-1680.

Stelwagen, K. 2001. Effect of milking frequency on mammary functioning and shape of the lactation curve. J. Dairy Sci. 84(E Suppl.):E204-E211.

Stelwagen, K., S. R. Davis, V. C. Farr, and S. J. Eichler. 1994. Effect of once daily milking and concurrent somatotropin on mammary tight junction permeability and yield of cows. J. Dairy Sci. 77:2994-3001.

Stelwagen, K., V. C. Farr, S. R. Davis, and C. G. Prosser. 1995. EGTAinduced disruption of epithelial cell tight junctions in the lactating caprine mammary gland. Am. J. Physiol. 269:R848-R855.

Stelwagen, K., V. C. Farr, and H. A. McFadden. 1999. Alteration of the sodium to potassium ratio in milk and the effect on milk secretion in goats. J. Dairy Sci. 88:52-59.

Stelwagen, K., V. C. Farr, H. A. McFadden, C. G. Prosser, and S. R. Davis. 1997. Time course of milk accumulation-induced opening of mammary tight junctions and blood clearance of milk components. Am. J. Physiol. 273:R379-R386.

Stull, M. A., V. Pai, A. J. Vomachka, A. M. Marshall, G. A. Jacob, and N. D. Horseman. 2007. Mammary gland homeostasis employs serotonergic regulation of epithelial tight junctions. Proc. Natl. Acad. Sci. USA 104:16708-16713. 